\title{
Meta-analysis of randomized controlled trials on the efficacy and safety of intracoronary administration of tirofiban for no-reflow phenomenon
}

\author{
Tao Qin ${ }^{1}$, Lu Xie ${ }^{2}$ and Meng-Hua Chen ${ }^{1 *}$
}

\begin{abstract}
Background: Currently, there is still a lack of an optimal treatment for no-reflow phenomenon (NR). The aim of this simple meta-analysis was to evaluate the efficacy and safety of intracoronary (IC) administration of tirofiban compared with other conventional drugs during percutaneous coronary intervention (PCl) for NR.

Methods: Systematic literature search was done from PubMed, EMBASE, Google Scholar, EBSCO, Springer and CNKI databases without language or time limitation. Randomized controlled trials were enrolled for analyzing if they investigated the treatment of IC administration of tirofiban versus other conventional drugs for NR.

Results: Ten studies with 702 patients were included. Significantly, the treatment of tirofiban was more effective in improving the thrombolysis in myocardial infarction (TIMI) flow (OR $0.24,95 \% \mathrm{Cl} 0.15-0.37, \mathrm{P}<0.00001)$ and reducing major adverse cardiovascular events (MACE) (OR 0.09, 95\% Cl 0.05-0.18, P<0.00001). There was a trend to increase the risk of bleeding, but the data of the result did not reach the statistical significance (OR $1.44,95 \% \mathrm{Cl}$ 0.69-3.00, $\mathrm{P}=0.32$ ).
\end{abstract}

Conclusions: Tirofiban is more effective than conventional drugs for NR during $\mathrm{PCl}$, but the potential risk of bleeding complication induced by tirofiban shouldn't be ignored during clinical practices.

\section{Background}

Currently, percutaneous coronary intervention (PCI) has become the most common strategy for acute coronary syndrome. No-reflow phenomenon (NR) is one of the serious complications of $\mathrm{PCI}$, which could lead to poor prognosis [1-3].

The conventional pharmacological treatment for NR is intracoronary (IC) administration of vasodilators (for example, adenosine, verapamil, nitroglycerin, sodium nitroprusside, etc.) [4]. So far, there are some randomized controlled trials investigated the treatment of IC administration of tirofiban for NR. But compared with conventional drugs, the treatment of tirofiban has not been evaluated. Therefore, the aim of this article was to compare the efficacy and safety of IC administration of

\footnotetext{
* Correspondence: cmhnn@sina.com

${ }^{1}$ Institute of Cardiovascular Diseases, the First Affiliated Hospital of Guangxi,

Medical University, Nanning, Guangxi, 530027, P. R. China

Full list of author information is available at the end of the article
}

tirofiban with conventional drugs for NR during PCI by performing a simple meta-analysis.

\section{Methods}

Search strategy

Completed randomized controlled trials that investigated the efficacy and safety of IC administration of tirofiban versus conventional drug for NR during PCI were sought out by searching the electronic databases, including PubMed, EMBASE, Google Scholar, EBSCO, Springer and CNKI. Separate search strategy was developed for each database using the following keywords: "no-reflow", "tirofiban", "glycoprotein $\alpha \mathrm{b} / \beta \mathrm{a}$ inhibitors", "intracoronary", "randomized controlled trial" and "percutaneous coronary intervention". The search was performed without language or time limitation. The types of articles such as comments, letters and the works that were not original reports were excluded. 


\section{Study selection}

Study was considered eligible if it met the following criteria: (i) the patients with NR during PCI were enrolled, (ii) randomly designed patients to a strategy of IC administration, either tirofiban or one of the conventional drugs, (iii) reported at least on one of following outcomes: transformation of thrombolysis in myocardial infarction (TIMI) flow after treatment, major adverse cardiovascular events (MACE) and bleeding complication. Methodological quality of the enrolled studies was assessed in relation to randomization and concealment of allocation. Quality scale was used to assess the trials: (A) true randomization and allocation concealed, and (B) process of randomization not given and concealment of allocation unclear. This approach was recommended by the Cochrane Collaboration [5].

\section{Data abstraction}

The following information were extracted from the enrolled studies: (i) first author's last name, publication year, (ii) study design, including the type and dosage of the IC drugs, duration of treatment, number of patients and the follow up, (iii) data of endpoints.
Outcome events were based on the definitions used in the individual trial publications. All data were independently extracted by two investigators (TQ and LX). Results were compared, and disagreements were resolved by discussion with a third investigator (MHC).

\section{Statistical analysis}

Data were entered and analyzed using the Cochrane Collaboration Review Manager software (version 5.2). The data of outcomes were analyzed separately by indications (transformation of TIMI flow after treatment, MACE, bleeding complication). Odds ratios (OR) and 95\% confidence intervals (CI) were calculated. Randomeffects models were used since heterogeneity was expected among the trials. And for unifying the outcomes in forest plots, we analyzed the incidence of TIMI 0-2 flow transformation after IC treatment, which could also reflex the incidence of TIMI 3 flow, which was a signal of restoration of myocardial perfusion. An $\mathrm{OR}<1$ suggested a beneficial effect whilst an OR $>1$ suggested a detrimental effect. Statistical significance was defined as a 2 - sided $\mathrm{p}$ value $<0.05$.

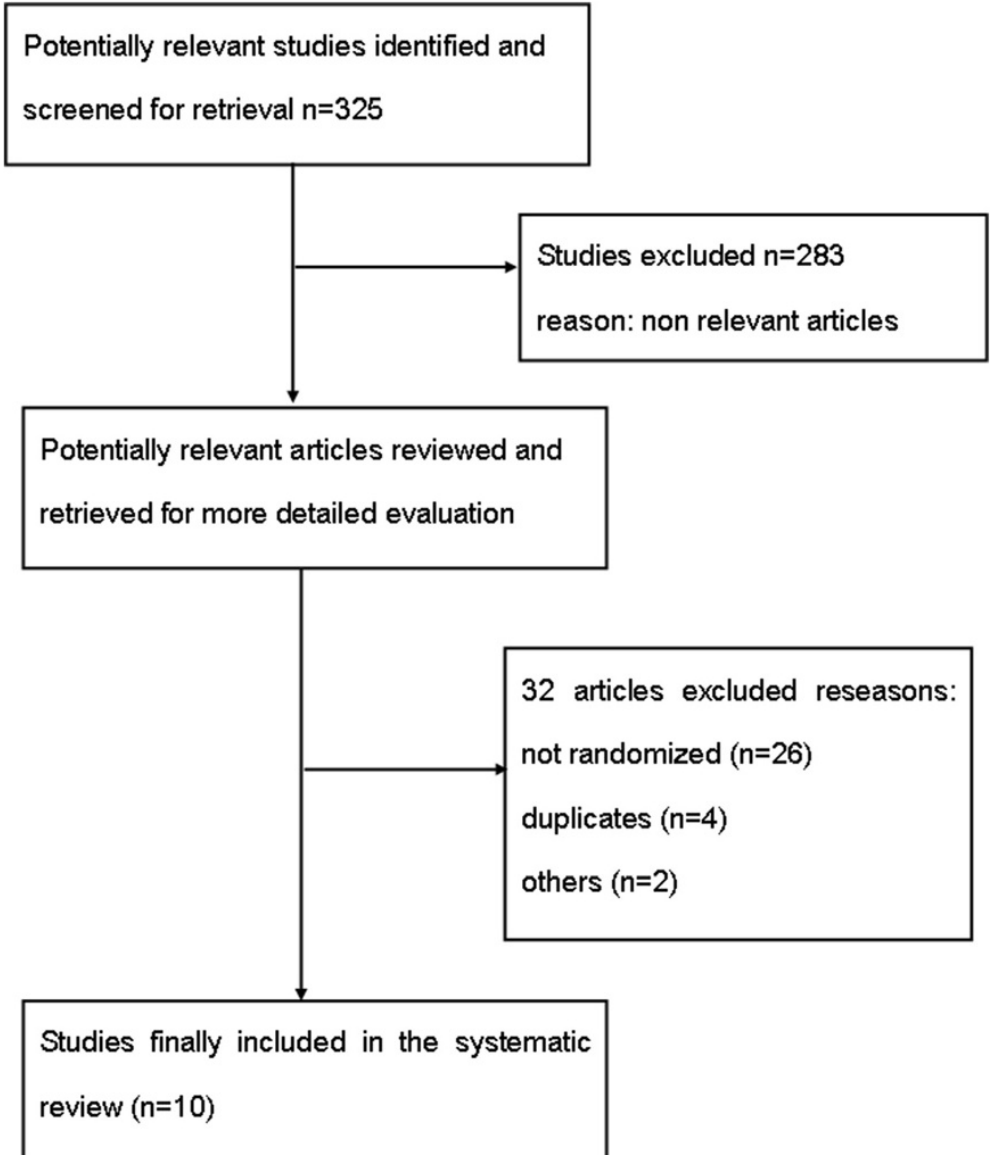

Figure 1 Search flow diagram of this meta-analysis. 


\section{Results}

Search results

With separate search strategy in each database, the search yielded 325 articles that were potentially pertinent. Reviewing titles and abstracts to exclude irrelevant studies, case reports, editorial comments, and reviews, 42 studies were retrieved for further consideration. Of the 42 studies, 32 studies were finally excluded mainly because they only administrated tirofiban additionally compared with the parallel control group. Ten [6-15] completed randomized trials fulfilled all the inclusion criteria and included 702 patients (Figure 1).

\section{Study characteristics}

The enrolled studies' characteristics are presented in Table 1. The studies published from 2007 to 2012. Described each study's characteristic and analyzed the quality scale. All the trials mentioned randomization and the comparability of baseline were offered, but not mentioned the concealment of allocation. After the quality analyzing, all trials were evaluated $B$. In the control group, there were 4 trials administrated with nitroglycerin $[6,9,10,12]$, 5 with verapamil $[7,9,11,14,15]$ and 1 with sodium nitroprusside [13].

\section{Quantitative data synthesis}

According to the data analysis, all the enrolled trials $(\mathrm{n}=$ 702) investigated the transformation of TIMI flow after the IC pharmacological treatment and the results found that tirofiban was more effective in improving the TIMI flow (OR 0.24, 95\% CI 0.15-0.37, P $<0.00001$, Figure 2). Furthermore, tirofiban significantly reduced the MACE (OR 0.09, 95\% CI 0.05-0.18, P $<0.00001$, Figure 3), but had a tendency to increase the risk of bleeding (OR 1.44, $95 \%$ CI $0.69-3.00, P=0.32$, Figure 4 ) in 6 of the 10 trials $(\mathrm{n}=359)[6,9,10,12,13,15]$.

Specifically, we compared tirofiban with each kind of conventional drugs for a further analysis of the transformation of TIMI flow. And it also indicated that tirofiban had its benefit of improving the coronary flow for NR (OR 0.24, 95\% CI 0.15-0.37, P = 0.001, Figure 5).

\section{Discussion}

NR could be defined as the persistence of reduced flow and regional myocardial dysfunction after the removal of an experimental epicardial coronary occlusion [16].

So far, the precise mechanisms of NR have not been fully clarified. The optimal therapy for NR is still being explored. Some studies [17-19] suggested that the dysfunction of coronary microcirculation perfusion was the central mechanism of NR. And it would not occur until the lesion of coronary microvascular endothelium to a certain extent. It was a dynamic and persistent procedure. Once the phenomenon occurred, the inflammation and lesion of coronary microvascular endothelium would be aggravated and the effect would sustain for weeks. A case report [20] showed that the phenomenon could be improved by taking appropriate intervention measures

Table 1 Study design of the included randomized controlled trials

\begin{tabular}{|c|c|c|c|c|c|c|c|c|}
\hline \multirow[t]{2}{*}{ Study } & \multirow[t]{2}{*}{$\mathrm{N}(\mathrm{T} / \mathrm{C})$} & \multicolumn{2}{|c|}{ Control group } & \multirow{2}{*}{$\begin{array}{l}\text { Conventional } \\
\text { drugs }\end{array}$} & \multirow[t]{2}{*}{ Tirofiban } & \multirow[t]{2}{*}{ Endpoints§ } & \multirow[t]{2}{*}{ Follow up } & \multirow[t]{2}{*}{ Quality* } \\
\hline & & Asp & Cpg & & & & & \\
\hline Chen2012 & $27 / 24$ & $\sqrt{ }$ & $\sqrt{ }$ & $\begin{array}{l}\text { Nitroglycerin } 200 \mu \mathrm{g} \text { within } 3 \text { mins } \\
\text { then IV } 0.15 \mu \mathrm{g} / \mathrm{kg} \cdot \mathrm{min} \text { for } 36-48 \mathrm{~h}\end{array}$ & $\begin{array}{l}10 \mu \mathrm{g} / \mathrm{kg} \text { within } 3 \text { mins then IV } \\
0.15 \mu \mathrm{g} / \mathrm{kg} \cdot \mathrm{min} \text { for } 36-48 \mathrm{~h}\end{array}$ & $(1)(2)(3)$ & $30 d$ & B \\
\hline Fu 2012 & $43 / 43$ & $\sqrt{ }$ & $\sqrt{ }$ & Verapamil 1 mg within 5 mins & $\begin{array}{l}10 \mu \mathrm{g} / \mathrm{kg} \text { within } 5 \text { mins then IV } \\
0.075 \mu \mathrm{g} / \mathrm{kg} \cdot \mathrm{min} \text { for } 24 \mathrm{~h}\end{array}$ & $(1)$ & - & B \\
\hline Guan 2012 & $40 / 40$ & - & - & Verapamil 1 mg within 5 mins & $\begin{array}{l}10 \mu \mathrm{g} / \mathrm{kg} \text { within } 5 \text { mins then IV } \\
0.075 \mu \mathrm{g} / \mathrm{kg} \cdot \mathrm{min} \text { for } 24 \mathrm{~h}\end{array}$ & $(1)$ & - & B \\
\hline He 2012 & $28 / 28$ & $\sqrt{ }$ & $\sqrt{ }$ & Nitroglycerin $200 \mu \mathrm{g}$ within 3 mins & $\begin{array}{l}10 \mu \mathrm{g} / \mathrm{kg} \text { within } 3 \text { mins then IV } \\
0.15 \mu \mathrm{g} / \mathrm{kg} \cdot \mathrm{min} \text { for } 24-48 \mathrm{~h}\end{array}$ & $(1)(2)(3)$ & $14 d$ & B \\
\hline Luan 2007 & $45 / 44$ & - & - & Nitroglycerin $200 \mu \mathrm{g}$ within 3 mins & $10 \mu \mathrm{g} / \mathrm{kg}$ within 3 mins & $(1)(2)(3)$ & $7 d$ & B \\
\hline Wang2012 & $48 / 34$ & $\sqrt{ }$ & $\sqrt{ }$ & Verapamil $200 \mu \mathrm{g}$ within 15 mins & $\begin{array}{l}10 \mu \mathrm{g} / \mathrm{kg} \text { within } 5 \text { mins then IV } \\
0.15 \mu \mathrm{g} / \mathrm{kg} \cdot \mathrm{min} \text { for } 38 \mathrm{~h}\end{array}$ & (1) & - & B \\
\hline Wei 2009 & $26 / 20$ & $\sqrt{ }$ & $\sqrt{ }$ & $\begin{array}{l}\text { Nitroglycerin } 200 \mu \mathrm{g} \text { within } 3 \text { mins } \\
\text { then IV } 0.15 \mu \mathrm{g} / \mathrm{kg} \cdot \mathrm{min} \text { for } 36-48 \mathrm{~h}\end{array}$ & $\begin{array}{l}10 \mu \mathrm{g} / \mathrm{kg} \text { within } 3 \text { mins then IV } \\
0.15 \mu \mathrm{g} / \mathrm{kg} \cdot \mathrm{min} \text { for } 36-48 \mathrm{~h}\end{array}$ & $(1)(2)(3)$ & $30 d$ & B \\
\hline Wu 2012 & $36 / 36$ & $\sqrt{ }$ & $\sqrt{ }$ & $\begin{array}{l}\text { Sodium nitroprusside } 0.9 \mu \mathrm{g} / \mathrm{kg} \\
\text { within } 3 \text { mins }\end{array}$ & $\begin{array}{l}10 \mu \mathrm{g} / \mathrm{kg} \text { within } 3 \text { mins then IV } \\
0.15 \mu \mathrm{g} / \mathrm{kg} \cdot \mathrm{min} \text { for } 24 \mathrm{~h}\end{array}$ & $(1)(2)(3)$ & $14 d$ & B \\
\hline Zhang 2010 & $46 / 49$ & $\sqrt{ }$ & $\sqrt{ }$ & Verapamil 1 mg within 5 mins & $\begin{array}{l}10 \mu \mathrm{g} / \mathrm{kg} \text { within } 5 \text { mins then IV } \\
0.075 \mu \mathrm{g} / \mathrm{kg} \cdot \mathrm{min} \text { for } 24 \mathrm{~h}\end{array}$ & (1) & - & B \\
\hline Zhang 2012 & $21 / 24$ & $\sqrt{ }$ & $\sqrt{ }$ & Verapamil $200 \mu \mathrm{g}$ within 3 mins & $\begin{array}{l}10 \mu \mathrm{g} / \mathrm{kg} \text { within } 3 \text { mins then IV } \\
0.15 \mu \mathrm{g} / \mathrm{kg} \cdot \min \text { for } 36-48 \mathrm{~h}\end{array}$ & $(1)(2)(3)$ & $30 d$ & B \\
\hline
\end{tabular}




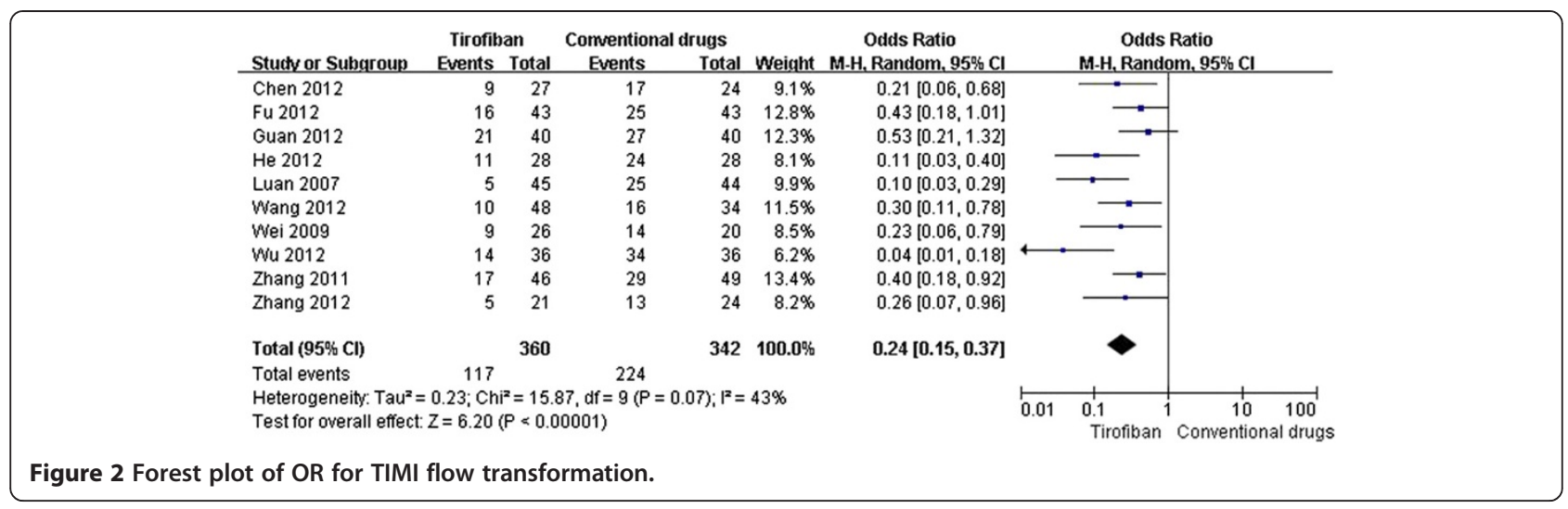

before the lesion. Restoration of myocardial perfusion rapidly could be achieved by removing the microvascular obstruction and recovering the antegrade coronary flow of occlusive vessel, and it has become a key of the treatment for NR [21].

For NR, the mechanism of conventional drugs was mainly for expanding the coronary vessel, which might be beneficial to allowing the formed microthrombus to get through the microvascular network and removing the coronary occlusion. On the basis of the mechanisms, conventional drugs could not inhibit the sustained thrombi caused by platelet aggregation when balloon was dilating, which limited the effect [22,23]. The effects of these vasodilators in patients with NR were contradictory and could not be sustained by large scale clinical evidence [24-29].

Platelet aggregation plays an important role in the formation of embolization. Glycoprotein IIb/IIIa inhibitors (GPI) block the final pathway of platelet aggregation, combine with the glycoprotein IIb/IIIa receptors selectively and inhibit the thrombinogen I competitively. And also, GPI could inhibit the activation, adhesion and aggregation of platelet. The pharmacological mechanisms of GPI were contributed to the formation of platelet thrombi, restoration the antegrade coronary flow of occlusive vessel and reducing the incidence of the ischemia event [30,31]. From the recent researches, GPI has its obvious advantages in inhibiting the formation of platelet thrombus, but bleeding event was the main complication [31,32]. Tirofiban is one kind of GPI, which with high selectivity and short-acting pharmacological mechanism [33]. During PCI, IC administration of tirofiban might increase the local drug concentration and improve the coronary flow. Considering the particular mechanism, tirofiban selectively blocks the final pathway of the platelet aggregation, which might contribute to the improving TIMI flow. And the short half-life might relative to the reducing of MACE.

Also, the bleeding event needs to be considered. By analyzing the enrolled trials of this article, 9 of the 10 trials had the administration of tirofiban by intravenous (IV) infusion after PCI with some degrees. Chen and Wei administrated both group with IV infusion $[6,12]$, while the other seven trials only with the tirofiban group [7-9,11-15]. Although it didn't reach the statistical significance, an increasing trend of bleeding was observed comparing with the conventional drugs. One of the possible explanations might be that IV infusion of tirofiban increased the drug concentration in the system and decreased the function of platelet which led to the bleeding complication. Kimmelstiel et al. [34] referred that the half-life of tirofiban was 2 hours, and the function of platelet could recover $89 \%$ of the baseline and the prothrombin time recovered completely after 2-4 hours of the drug withdrawal. In a study by Zhang WZ et al. [35] of IC administration tirofiban for NR, if the effect was

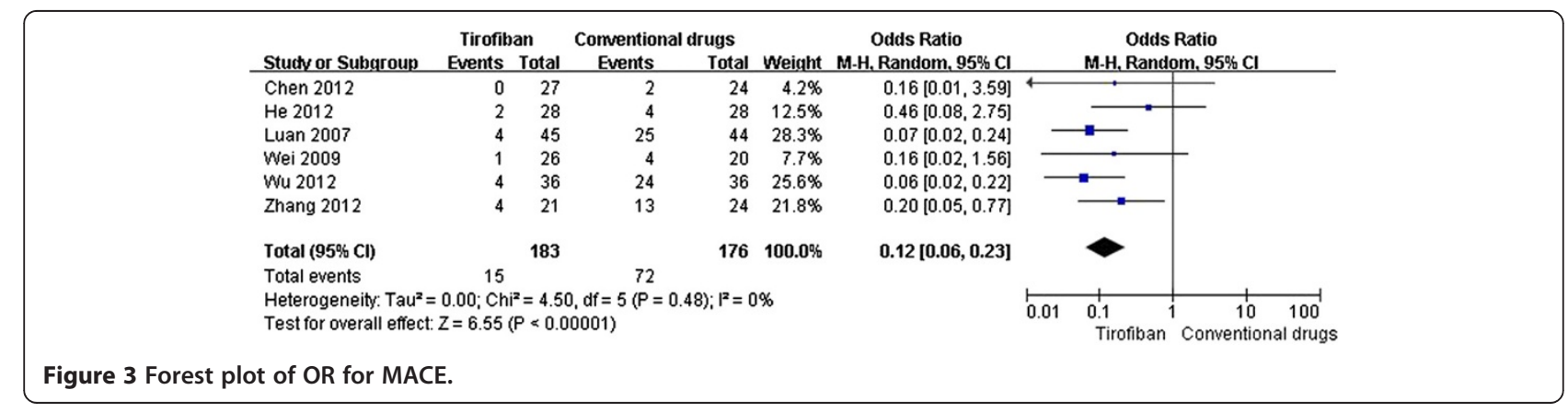




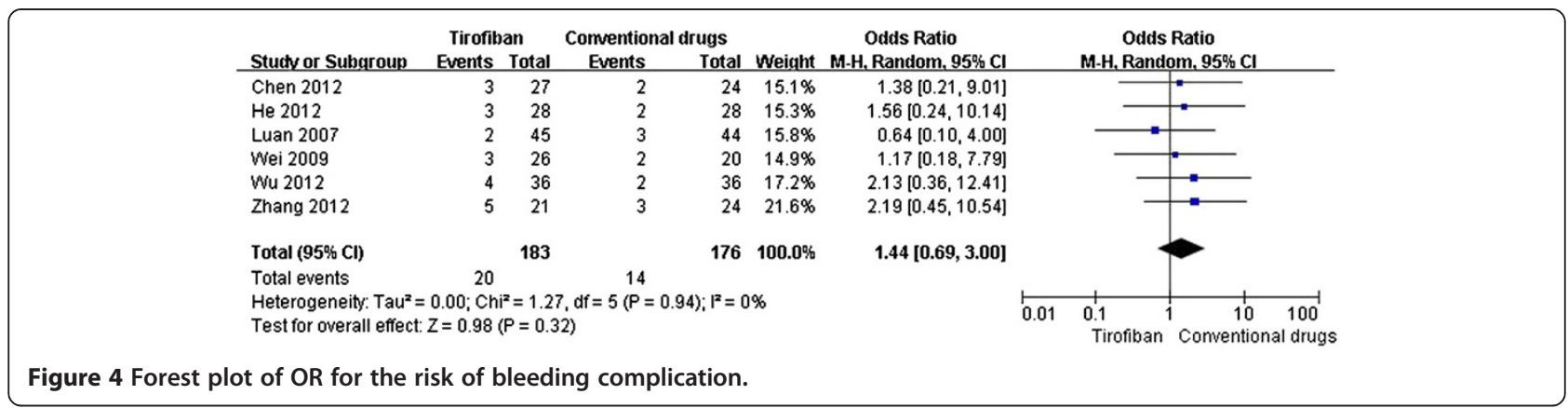

not satisfied during the PCI, then continually IV infused for 24-hour post-operation could improve the antegrade coronary flow of occlusive vessel. But from a metaanalysis by Geeganage $C$ et al. [36], it suggested that the additional IV administration of GPI increased the bleeding event. However, the administration of post-operative IV infusion of tirofiban for NR, whether or how it should be, needs to be confirmed by further clinical investigations.

\section{Study limitations}

Though TIMI is a classical indicator of reperfusion during PCI [37-39], it doesn't mean that TIMI 3 flow represents a normal myocardial perfusion [40]. In other words, myocardial blush grade (MBG) 0-1 might occur in the patients with TIMI 3 flow during PCI. It had been found that MBG was an independent predictor of long-term mortality and could be used to describe the effectiveness of myocardial reperfusion [41]. Van't Hof et al. [42] proposed that the angiographic definition of successful reperfusion should include both TIMI 3 flow as well as MBG 2 or 3. Moreover, Stone et al. [43] suggested that MBG could be used to stratify prognosis of survival in high risk patients achieving TIMI 3 flow after intervention. Theoretically, MBG is superior to TIMI when assessing the myocardial perfusion during PCI. Unfortunately, we didn't use MBG as an indicator in the present study, because only one of the ten enrolled studies provided the data of TIMI as well as MBG in the comparison of trofiban versus verapamil [7].

As all the enrolled trials' quality scales were B and with small sample data, the bias should not be ignored. Also, the condition of patients, the time and dosage of 
different administrations and the different selections of the conventional drugs might have influenced the outcomes. Therefore, it needs further powerful randomized trials to investigate the treatment.

\section{Conclusions}

The treatment of IC administration of tirofiban is more effective than the conventional drugs for NR, but the potential risk of bleeding complication induced by the drug shouldn't be ignored during clinical practices. From this meta-analysis, it suggested that the safety of IC administration of tirofiban for NR should be fully considered the individuation of patients and balanced the efficacy and the hazard.

\section{Competing interests}

The authors declare that they have no competing interests.

\section{Authors' contributions}

TQ conceived the study, participated in the design, collected the data, and drafted the manuscript. LX participated in the design, collected the data, performed statistical analyses and drafted the manuscript. MHC conceived the study, participated in the design, and helped to draft the manuscript. All authors read and approved the final manuscript.

\section{Authors' information}

Tao Qin and Lu Xie are co-first author.

\section{Acknowledgements}

There was no external funding source for this research.

\section{Author details}

${ }^{1}$ Institute of Cardiovascular Diseases, the First Affiliated Hospital of Guangxi, Medical University, Nanning, Guangxi, 530027, P. R. China. ${ }^{2}$ Department of Physiology, School of Pre-Clinical Sciences, Guangxi Medical University, Nanning, Guangxi, 530027, P. R. China.

Received: 11 March 2013 Accepted: 28 August 2013

Published: 10 September 2013

\section{References}

1. Vallejo E, Pena D, Norono O, Ban Hayashi E, Gaspar J, Villavicencio R, Martinez Rios MA: The slow-reflow phenomenon: its incidence and clinical characteristics in aseries of cases. Arch Inst Cardiol Mex 1998, 68:247-252.

2. Morishima I, Sone T, Okumura K, Okumura K, Tsuboi H, Kondo J, Mukawa H, Matsui H, Toki Y, Ito T, Hayakawa T: Ngiographic slow-reflow phenomenon: as a predictor of adverse long term outcome in patients treated with percutaneous transluminal coronary angioplasty for first acute myocardial infarction. J Am Coll Cardiol 2000, 36:1202-1209.

3. Brosh D, Assali AR, Mager A, Porter A, Hasdai D, Teplitsky I, Rechavia E, Fuchs S, Battler A, Kornowski R: Effect of no-reflow during primary percutaneous coronary intervention for acute myocardial infarction on six-month mortality. Am J Cardiol 2007, 99:442-445.

4. Ramjane $K$, Han L, Jin C: The diagnosis and treatment of the no-reflow phenomenon in patients with myocardial infarction undergoing percutaneous coronary intervention. Exp Clin Cardiol 2008, 13:121-128.

5. Higgins JPT, Green S: Cochrane handbook for systematic reviews of interventions. London: Wiley Interscience; 2008.

6. Chen SF, Liu HM, Li YS: Efficacy and safety of intracoronary tirofiban on noreflow patients after $\mathrm{PCl}$ in acute coronary syndrome. Tianjin Pharm 2012, 24:18-20.

7. Fu W: Effects of tirofiban in elder patients of acute myocardial infarction with noreflow phenomenon during PCl. Chin J Gerontol 2012, 8:1565-1567.
8. Guan XS: The clinical impact of tirofiban on slow flow or no-reflow of post-PCl in patients with acute myocardial infarction. Chin J of Med Guide 2012, 14:268,243.

9. He DM, Huang JZ: The efficacy and safety of tirofiban for no-reflow phenomenon in acute coronary syndrome during $\mathrm{PCl}$. Chin Community Doctors 2012, 7:56-57.

10. Luan $B$, Han $Y L$, Jing QM, Jing QM, Wang SL, Ma YY, Wang G, Wang B: Efficacy of intracoronary administration of tirofiban for no-reflow during emergency PCl. Shenyang Army Med 2007, 20:367-369.

11. Wang YP, Ding MX, Zhao SW: Clinical observation of tirofiban treatment on no-flow phenomenon in patients with acute ST-elevation myocardial infarction during percutaneous coronary intervention. Tianjin Med J 2012, 40:159-160.

12. Wei $L$, $L i X Q$, Jin $E Z$, Wang $X Y$ : Efficacy and safety of intracoronary tirofiban on no-ref low pati phenomenon after percutaneous coronary intervention. J Clin Cardiol (China) 2011, 27:25-29.

13. Wu J, Xu L, Du H, Wang YR: Influence of tirofiban on no-reflow after percutaneous coronary intervention in patients with acute coronary syndrome. Chin J Evid Based Cardiovasc Med 2012, 14:131-133.

14. Zhang HY, Wang PX, Cao YJ, Wu ZG, Liu HS: Clinical study of intracoronary injections of tirofiban in acute myocardial infarction patients with no reflow phenomenon after percutaneous coronary intervention. J Clin Cardiol (China) 2011, 27:25-29.

15. Zhang J, Jiang JG: Effects of intracoronary injections of tirofiban in acute coronary syndrome patients with no reflow phenomenon after percutaneous coronary intervention. Anhui Med J 2012, 2:155-158.

16. Piana RN, Paik GY, Moscucci M, Cohen DJ, Gibson CM, Kugelmass AD, Carrozza JP Jr, Kuntz RE, Baim DS: Incidence and treatment of 'no-reflow' after percutaneous coronary intervention. Circulation 1994, 89:2514-2518.

17. Niccoli G, Burzotta F, Galiuto L, Crea F: Myocardial no-reflow in humans. J Am Coll Cardiol 2009, 54:281-292.

18. Chen YF, Yang YJ: No-reflow phenomenon after percutaneous coronary intervention. Adv Cardiovasc Dis Jan 2005, 26:4-8.

19. Rittersma SZ, van der Wal AC, Koch KT, Piek JJ, Henriques JP, Mulder KJ, Ploeqmakers JP, Meesterman M, de Winter RJ: Plaque instability frequently occurs days or weeks before occlusive coronary thrombosis. Circulation 2005, 111:1160-1165.

20. Movahed MR, Butman SM: The pathogenesis and treatment of no-reflow occurring during percutaneous coronary intervention. Cardiovasc Revase Med 2008, 9:56-61.

21. Lee $\mathrm{CH}$, Wong HB, Tan HC, Zhang JJ, Teo SG, Ong Low A, Sutandar A, Lim $Y T$ : Impact of reversibility of no reflow phenomenon on 30-day mortality following percutaneous revascularization for acute myocardial infarction-insights from a 1,328 patient registry. J Interv Cardiol 2005, 18:261-266.

22. Pan W, Wang LF, Yu JH, Fan Y, Yang SS, Zhou LJ, Li Y, Li WM: Intracoronary nitroprusside in the prevention of the no-reflow phenomenon in acute myocardial infarction. Chin Med J 2009, 122:2718-2723.

23. Zhao HY: Effects of adenosine in reperfusion of acute myocardial infarction. China PracMed 2009, 4:71-72.

24. Resnic FS, Wainstein M, Lee MK, Behrendt D, Wainstein RV, Ohno-Machado L, Kirshenbaum JM, Rogers CD, Popma JJ, Piana R: No-reflow is an independent predictor of death and myocardial infarction after percutaneous coronary intervention. Am Heart J 2003, 145:42-46.

25. Kaplan BM, Benzuly KH, Kinn JW, Bowers TR, Tilli FV, Grines CL, O'Neill WW, Safian RD: Treatment of no-reflow in degenerated saphenous vein graft interventions: comparison of intracoronary verapamil and nitroglycerin. Cathet Cardiovasc Diagn 1996, 39:113-118.

26. Michaels AD, Appleby M, Otten MH, Dauterman K, Ports TA, Chou TM, Gibson CM: Pretreatment with intragraft verapamil prior to percutaneous coronary intervention of saphenous vein graft lesions: results of the randomized, controlled vasodilator prevention on no reflow (VAPOR) trial. J Invasive Cardiol 2002, 14:299-302.

27. Oldenburg $\mathrm{O}$, Eggebrecht $\mathrm{H}$, Herrmann J, Naber CK, Haude M, Erbel R, Baumgart D: Dose-dependent effects of in tracoronary verapamil on systemic and coronary hemodynamics. Cardiovasc Drugs Ther 2000, 14:651-655.

28. Ishihara M, Sato H, Tateishi H, Kawagoe T, Shimatani Y, Ueda A, Kurisu S: Effects of various doses of intracoronary diltiazem on coronary resistance vessels in humans. Jpn Circ J 1995, 5912:790-798.

29. Huang D, Qian J, Ge L, Jin X, Jin H, Ma J, Liu Z, Zhang F, Dong L, Wang X, Yao K, Ge J: REstoration of coronary flow in patients with no-reflow after 
primary coronary intervention of acute myocardial infarction (RECOVER). Am Heart J 2012, 164:394-401.

30. Topol EJ, Byzova TV, Plow EF: Platelet GPIllb-llla blockers. Lancet 1999, 353:227-231.

31. Warnhol A, Ostad MA, Heitzer T, Goldmann BU, Nowak G, Munzel T: Effect of tirofiban on percutaneous coronary intervention-induced endothelial dysfunction in patients with stable coronary artery disease. Am J Cardiol 2005, 95:20-23.

32. Stangl PA, Lewis S: Review of currently available GP IIb/llla inhibitors and their role in peripheral vascular interventions. Semin Intervent Radiol 2010, 27:412-421.

33. Kouz R, Kouz S, Schampaert E, Rinfret S, Tardif JC, Nguyen M, Eisenberg M, Harvey R, Afilalo M, Lauzon C, Dery JP, Mansour S, Huynh T: Effectiveness and safety of glycoprotein Ilb/llla inhibitors in patients with myocardial infarction undergoing primary percutaneous coronary intervention: a meta-analysis of observational studies. Int J Cardiol 2011, 153:249-255.

34. Kimmelstiel C, Badar J, Covic L, Waxman S, Weintraub A, Jacques S, Kuliopulos A: Pharmacodynamics and pharmacokinetics of the platelet GPIllb /llla inhibitor tirofiban in patients undergoing percutaneous coronary intervention: implications for adjustment of tirofiban and clopidogrel dosage. Thromb Res 2005, 116:55-66.

35. Zhang WZ, Song MC, Liang JY, Li JH, Lei HD, Su JQ, Chen GQ: Effects of tirofiban in patients with no reflow during $\mathrm{PCl}$ procedure. South China $\mathrm{J}$ Cardiovasc Dis 2008, 14:103-105.

36. Geeganage C, Wilcox R, Bath PMW: Triple antiplatelet therapy for preventing vascular events: a systematic review and meta-analysis[J]. BMC Med 2010, 8:36

37. Hamada S, Nishiue $T$, Nakamura $S$, Sugiura T, Kamihata H, Miyoshi $H$, Imuro Y, Iwasaka T: TIMI frame count immediately after primary coronary angioplasty as a predictor of functional recovery in patients with TIMI 3 reperfused acute myocardial infarction[J]. J Am Coll Cardiol 2001, 38(3):666-671.

38. Rezkalla SH, Kloner RA: Coronary no-reflow phenomenon: from the experimental laboratory to the cardiac catheterization laboratory[J]. Catheter Cardiovasc Interv 2008, 72(7):950-957.

39. Ndrepepa G, Tiroch K, Keta D, Fusaro M, Seyfarth M, Pache J, Mehilli J, Schomig A, Kastrati A: Predictive factors and impact of no reflow after primary percutaneous coronary intervention in patients with acute myocardial infarction[J]. Circ Cardiovasc Interv 2010, 3(1):27-33.

40. Stone GW, Brodie BR, Griffin JJ, Morice MC, Costantini C, Goar FST, Overlie PA, Popma JJ, McDonnell J, Jones D, O'Neill WW, Grines CL: Prospective, multicenter study of the safety and feasibility of primary stenting in acute myocardial infarction: in-hospital and 30-Day results of the PAMI stent pilot trial J]. J Am Coll Cardiol 1998, 31(1):23-30.

41. Van't Hof AW, Liem A, Suryapranata H, Hoorntje JC, De Boer MJ, Zijlstra F: Angiographic assessment of myocardial reperfusion in patients treated with primary angioplasty for acute myocardial infarction myocardial blush grade[J]. Circulation 1998, 97(23):2302-2306.

42. Henriques JP, Zijlstra F, Van't Hof AW, De Boer MJ, Dambrink JH, Gosselink $\mathrm{M}$, Hoorntje JC, Suryapranata $\mathrm{H}$ : Angiographic assessment of reperfusion in acute myocardial infarction by myocardial blush grade[J]. Circulation 2003, 107(16):2115-2119.

43. Stone GW, Peterson MA, Lansky AJ, Dangas G, Mehran R, Leon MB: Impact of normalized myocardial perfusion after successful angioplasty in acute myocardial infarction[J]. J Am Coll Cardiol 2002, 39(4):591-597.

doi:10.1186/1471-2261-13-68

Cite this article as: Qin et al:: Meta-analysis of randomized controlled trials on the efficacy and safety of intracoronary administration of tirofiban for no-reflow phenomenon. BMC Cardiovascular Disorders 2013 13:68.

\section{Submit your next manuscript to BioMed Central and take full advantage of:}

- Convenient online submission

- Thorough peer review

- No space constraints or color figure charges

- Immediate publication on acceptance

- Inclusion in PubMed, CAS, Scopus and Google Scholar

- Research which is freely available for redistribution

Submit your manuscript at www.biomedcentral.com/submit
() Biomed Central 